Iryna Drach,

Candidate of Technical Sciences, Associate Professor of the Department of Intellectual Property and Project Management, National Metallurgical Academy of Ukraine (Dnipro, Ukraine);

Halyna Yevtushenko, Candidate of Technical Sciences, Associate Professor of the Department of Information Technology and Systems, National Metallurgical Academy of Ukraine (Dnipro, Ukraine)

\title{
MANAGERIAL DECISION-MAKING IN THE FIELD OF INTELLECTUAL PROPERTY ON THE BASIS OF MULTIPLE-CRITERIA DECISION ANALYSIS
}

The process of supporting the acceptance of managerial decisions at the stage of acquiring rights to a computer program based on multi-criteria analysis methods is considered. The methods of legal protection of a computer program are investigated: as a literary work, invention and a sign for goods and services. We characterized forms of legal protection of a computer program according to the criteria: the size of legal protection; conditions for acquiring rights; complexity of expertise; expenses incurred in acquiring intellectual property rights; the duration of property rights protection. On the basis of the developed intensity scale, the priorities of protection methods according to each criterion were evaluated. The diagram of priorities of protection methods by the analytic networks process and analytic hierarchy process has been constructed.

Keywords: intellectual property, computer program, legal protection, commercialization, analytic network process, analytic hierarchy process.

DOI: 10.21272/mmi.2018.1-15

Introduction. In the era of knowledge economy, the basis for the development of society are nonmaterial resources, in particular, the results of creative intellectual activity of a person, which are transformed into objects of intellectual property rights. In accordance with the definition given by the World Intellectual Property Organization, intellectual property refers to creations of the mind, such as inventions; literary and artistic works; designs; and symbols, names and images used in commerce [1]. Each of the intellectual property objects has its own life cycle, which traditionally consists of the following steps: creation, acquisition of rights, commercialization, protection of rights and utilization [2]. At each stage of the life cycle of an intellectual property object, the rights owner faces with the necessity of making managerial decisions regarding to the appropriate form of legal protection, the choice of usage method, etc. As the processes of informatization and computerization penetrate all spheres of human activity, the issue of making managerial decisions regarding to the protection of such objects of intellectual property as computer programs, websites, databases is extremely relevant.

Analysis of recent researches and publications. Problems of making managerial decisions in the field of intellectual property are discussed in many scientific papers. For example, in M.V. Paladii's article [3] the principles of the formation of managerial decisions in the field of intellectual property are explored: purposefulness, functional compliance, timeliness of decision, reality of action, finality, sustainability, systematicity, implementation, regularization of decisions.

Work of S.R. Vodorzezova [4] is devoted to the analysis of the state of the legal mechanism for the rights protection to such information products as computer programs and databases. It is noted that a computer program may be protected as an object of copyright, invention and industrial pattern.

In D. Zhuvanov's, E. Stognii's [5] article the analysis of the advantages and disadvantages of the patent and copyright law forms of computer program protection and the ways of improving the system of its protection are offered.

The issues of improving the legal protection of a computer program in the conditions of the dynamic 
development of IT market are considered in the article by N.V. Filyk, G.V. Omelchenko [6]. The authors investigate the peculiarities of the legal protection of computer programs by the norms of copyright and the possibility of protecting individual elements of computer software by the rules of patent law.

Thesis research by S.A. Petrenko [7] is devoted to the improvement of legal protection mechanism of a computer program, which is considered as a sophisticated complex object of intellectual property rights. This complexity in its turn involves the application of the norms of copyright and industrial property rights in the legal protection process of certain elements of the computer program, as well as the existence of an accelerated procedure for obtaining legal protection on a computer program similar to that applicable to industrial patterns and utility models.

In K.V. Efremova's work [8] the advantages and disadvantages of computer program protection within the size of copyright, as well as the peculiarities of the patenting of the program algorithm as a process and the registration of a computer program as a trademark were explored.

Problems of legal protection of computer programs are also widely researched in foreign publications. For instance, in paper of A. Story [9], which is devoted to the relevance and impact of intellectual property rights on new technologies and software development, the computer program is represented by the object of copyright protection, patent law and commercial secrets.

R.M. Ballardini's book [10] provides a thorough analysis of copyright and patent law enforcement issues in Europe and America.

In papers of S.A. Shaikh, B.R. Londhe [11] it is noted that the software has a "hybrid nature", because it is divided into different categories, depending on its complexity, applicability, implementation. In connection with this, there is an opportunity to choose the method of legal protection of a software product: as an object of copyright, patent law and commercial secrets.

The necessity of ensuring the comprehensive legal protection of a computer program by means of patent and copyright is substantiated in the work of O. Borovskaya, S.L. Yermakovich, etc. [12]. The authors note that patent protection should not exclude, but complement the protection of computer software by copyright. Such combination will allow us to create a system that provides an effective and complete protection of the interests of software developers.

Characteristics of analytic hierarchy process and analytic network process, as well as examples of their application, are given in T.L. Saati's work [13]. These methods are a powerful system analysis tool and allow receiving support for a weighted decision taking into account factors essential for a particular case. In T.L. Saati's paper [14] the approach to relative measurements based on the main own vector of the matrix of pair comparisons was considered, as well as a list of scientific and practical problems were solved using analytic hierarchy process.

Selection of outstanding issues. Mentioned scientific works do not propose methods that would allow to systematize and increase the validity of the process of decision supporting of managerial decisions regarding the appropriate form of legal protection of intellectual property objects.

The aim of this article is to solve the model task of making managerial decisions at the stage of the acquisition of a computer program rights based on multiple-criteria decision analysis.

Main material. The foreign experience of legal protection of computer programs testifies to the application of different approaches. For instance, in the USA, at the legislative level since 1980, computer programs have been included in copyright objects. USA's following example was imitated by the most industrialized countries: Australia - 1984, France, United Kingdom, Japan - 1985, China - 1990.

At the same time, in the United States, in practice, the most liberal system of patent protection of decisions related to computer programs, which exists in parallel with the granting of protection under the copyright, is currently used.

In Europe, programming-related inventions involving algorithms are patented only if they result in a technical result. It is believed that a computer program has a technical character, if it is a source of 
technical influence when working on a computer [12].

As you know, computer programs in Ukraine are protected by copyright as literary works, that is, the protection is subject to the program code. The Law of Ukraine "On Copyright and Related Rights" [9] defines a computer program as a set of instructions presented in the form of numbers, words, codes, schemes, signs, or in any other form that can read the computer, and which brings it into effect in order to achieve the desired goal or result.

Copyright is distributed to all types of computer programs. These can be corporate information systems, Internet clients, database management systems, security tools, text and image editors, video games, drivers for a variety of devices, etc. It can be both applications and operating systems, as well as software systems. The program can be embedded in the processor itself of any technical device. The size of the program, the number of programming languages used, files or lines of the code does not matter to the copyright.

The second way to implement the legal protection of a computer program is the use of the patent system. This became possible due to the fact that in the latest edition of the Law of Ukraine "On Protection of Rights to Inventions and Utility Models" [16] the computer program was removed from the list of objects that are not provided with legal protection as inventions and utility models. In this case, the object of legal protection will no longer be the code of the program, and the algorithm on which it is based, that is, the way to solve the problem.

In addition to the patent and copyrighted forms of computer program protection, it is possible to register the program name as a sign for goods and services (trademark). In accordance with the Law of Ukraine "On the Protection of Rights to Trademarks for Goods and Services" [17], the sign is the notation by which the goods and services of some people are different from the goods and services of other people.

Thus, there are three real and effective ways of protecting the software today, as shown in Figure 1.

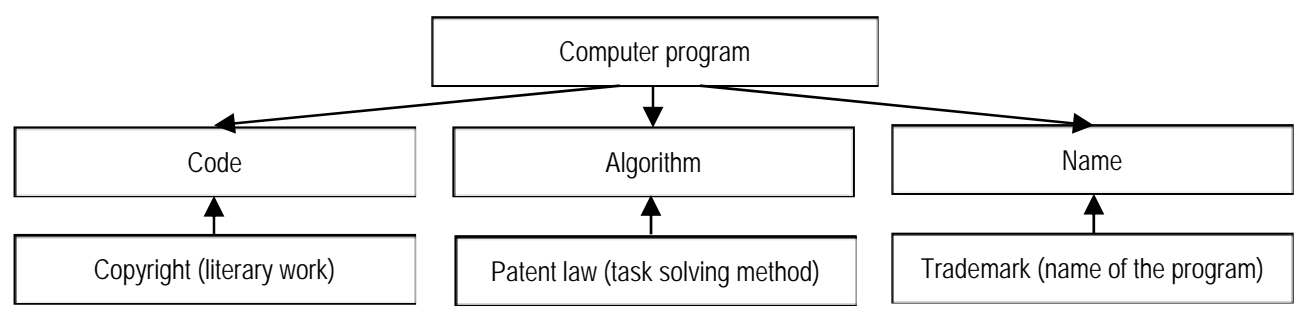

Figure 1 - Options for legal protection of a computer program

Deciding on the appropriate form of legal protection of a computer program should be based on an analysis of the advantages and disadvantages of each form, as well as the goals and capabilities of the enterprise in which it will be used.

For decision support tasks, which need to take into account a number of factors, it is expedient to apply methods of multi-criteria analysis. However, before choosing a particular method it is necessary to investigate the structure of the problem (system problem), that is to distinguish the following elements: goals, criteria, alternatives, variants of external conditions.

Choosing the right form of legal protection for a computer program is a strategic decision at the stage of acquiring rights and may include several goals. On the one hand, it is the choice of a security document for obtaining exclusive rights to a computer program (Goal 1), on the other hand, the choice of a security document for the further commercialization of the computer program (Goal 2).

Based on analysis of possible options for legal protection of a computer program, the following criteria for their evaluation are set: the size of legal protection (Cr1); conditions for acquiring rights ( $\mathrm{Cr} 2$ ); complexity of expertise ( $\mathrm{Cr} 3)$; expenses when acquiring copyrights ( $\mathrm{Cr} 4)$; the duration of the protection of property rights $(\mathrm{Cr} 5)$. 
І.Є.Драч, ГЛ. Євтушенко. Прийняття управлінських рішень у сфері інтелектуальної власності на основі багатокритеріального аналізу

Consider the description of the forms of legal protection of the computer program according to these criteria.

1. Copyright:

1.1. The size of legal protection: the form of the embodiment of the idea is subject to protection - the code as a literary work.

1.2. Conditions of acquiring rights: creative character, the presence of an objective form.

1.3. Complexity of expertise: registration is not a mandatory procedure; during examination of the application, the State Service does not conduct an examination of the work and does not establish the occurrence of authorship; consideration of the application, the decision on registration and issuance of the certificate is made in the term up to 2 months from the date of filing the application.

1.4. Expenses during the acquisition of intellectual property rights:

- preparation of state registration of copyright for legal entities - 161,50 UAH;

- registration of work copyright registration certificate from legal entities $-25,50 \mathrm{UAH}$.

1.5. The duration of the property rights protection: from the day the work was created, the entire life of the author and 70 years after his death.

2. Patent law:

2.1. Size of legal protection: the protection is subject to the essence of a computer program - an algorithm as a way to solve the problem.

2.2.Conditions of acquiring rights: novelty, inventive level, industrial suitability (invention); novelty, industrial suitability (utility model).

2.3. The complexity of the examination: the examination of the application consists of a preliminary examination, a formal examination, and, at the request for a patent for an invention, a qualification examination (in practice, the examination on the application for an invention lasts from 15 months, the term for obtaining a patent for an invention - 24-30 months, examination on the application the utility model lasts about 1,5 months, the term for obtaining such patent for a utility model is more than 6 months).

2.4. Costs incurred in acquiring intellectual property rights:

- submission of an application (utility model), the formula of which contains no more than three items - $800 \mathrm{UAH}$;

- conducting a qualification examination of an application for an invention whose formula has one independent item - 3,000 UAH;

- additionally, for each independent item of the claims of more than one - 3,000 UAH;

- publication on granting of a patent for an invention (utility model) - $200 \mathrm{UAH}$;

- additionally, for each sheet in excess of 15 sheets of the description, drawings and claims (utility

model) and abstract (total) contained in the application - $10 \mathrm{UAH}$;

- annual fee for maintaining the patent for an invention for each year of the patent's operation from the date of filing the application - 300-3800 UAH; for a utility model - from 300 to 2,100 UAH;

- the fee for issuing a patent for an invention (utility model) - $17 \mathrm{UAH}$.

2.5. Duration of property rights protection: 20 years from the date of filing an application (invention); 10 years from the filing date (utility model).

3. The right to commercial designation:

3.1. Size of legal protection: letters, numbers and other marks or words that are the name of the program are protected.

3.2. Terms of acquiring rights: legal protection is given to a sign that does not contradict public order, the principles of humanity, morals, etc.

3.3. Complexity of expertise: examination consists of formal and qualification examinations (lasts about 1,5-2 years).

3.4. Costs incurred in acquiring intellectual property rights: 
- filing an application for a single applicant - $1000 \mathrm{UAH}$;

- additional for each class of the International Classification of Goods and Services over one, the number of which is indicated in the application - $1000 \mathrm{UAH}$;

- publication on the issue of a certificate for a sign for goods and services in black and white for each class - $150 \mathrm{UAH}$;

- state duty for issuing a certificate for a sign for goods and services - $85 \mathrm{UAH}$.

3.5.Duration of property rights protection: 10 years from the date of filing an application with the possibility of renewal every 10 years.

Note that these forms can be combined, for example, to get the right both for the algorithm and the name of the program. Therefore, as alternatives, we consider both classical forms and their combinations (Table 1).

Table 1 - Options for legal protection of a computer program

\begin{tabular}{|c|c|c|}
\hline № & Full name of alternative & Abbreviation \\
\hline A1 & Certificate of work copyright registration & CCR \\
\hline A2 & Certificate of a sign for goods and services & SGS \\
\hline A3 & Patent for invention & Patent \\
\hline A4 & Certificate of work copyright registration + Certificate of a sign for goods and services & CCR + SGS \\
\hline A5 & Patent for invention + Certificate of a sign for goods and services & Patent + SGS \\
\hline A6 & Patent for invention + Certificate of work copyright registration & Patent + CCR \\
\hline A7 & $\begin{array}{c}\text { Patent for invention + Certificate of work copyright registration + Certificate of a sign for } \\
\text { goods and services }\end{array}$ & Patent + CCR + SGS \\
\hline
\end{tabular}

Thus, the structure of the problem under study is as follows (Fig. 2).

It is decided to add feedback to take into account the impact of the criteria on each other as well as on the goals. To solve system problems containing horizontal connections and feedbacks, the analytic network process is used.

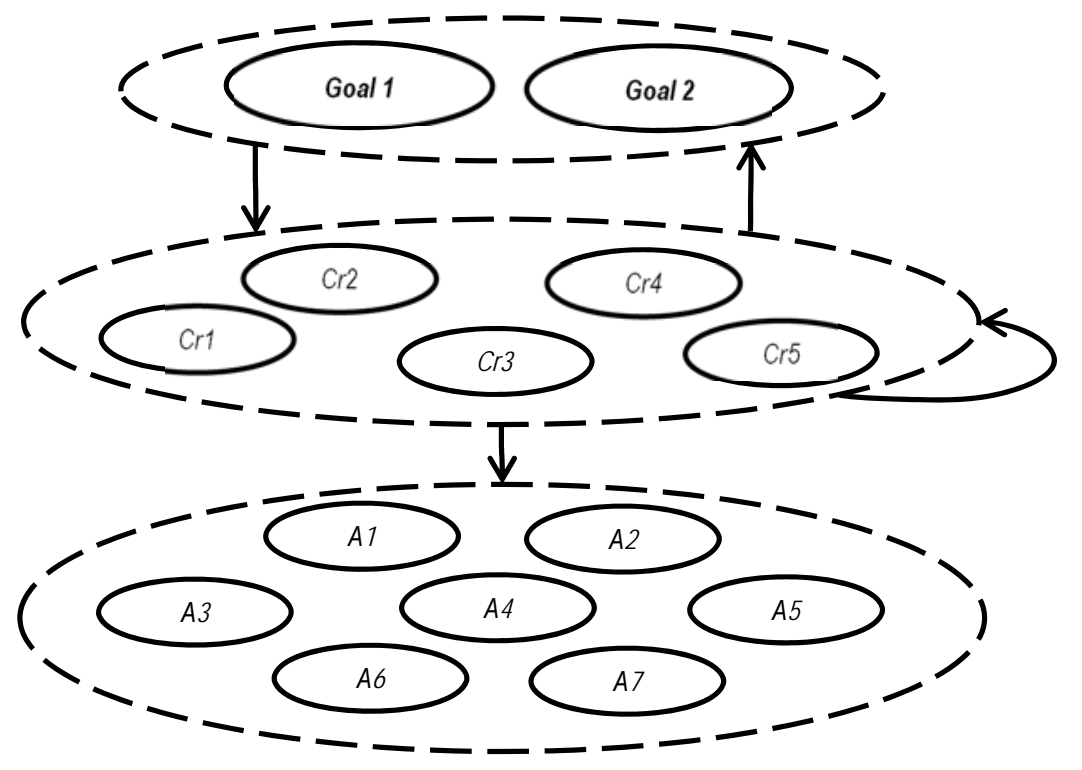

Figure 2 - Graph of the problem 
І.Є.Драч, ГЛ. Євтушенко. Прийняття управлінських рішень у сфері інтелектуальної власності на основі багатокритеріального аналізу

The analytic network process (ANP) is a further development of the analytic hierarchy process (AHP) developed by T.L. Saati $[9,10]$. AHP is an integral part of ANP's individual case. The analytic network process makes it possible to investigate the influences in general hierarchies, as well as network structures of problems $[9,10]$. The numerical model in ANP is a supermatrix [10] - a matrix that shows numerically the mutual influence of elements in a network or in a hierarchy (Table 2).

Table 2 - Matrix representation of the problem structure, supermatrix

\begin{tabular}{|c|c|c|c|c|}
\hline & & Goals & Criteria & Alternatives \\
\hline \multirow{3}{*}{$W=$} & Goals & $W_{11}$ & $W_{12}$ & $W_{13}$ \\
\cline { 2 - 5 } & Criteria & $W_{21}$ & $W_{22}$ & $W_{23}$ \\
\cline { 2 - 5 } & Alternatives & $W_{31}$ & $W_{32}$ & $W_{33}$ \\
\hline
\end{tabular}

Elements $W_{i j}$ in supermatrix $W$ are named blocks, which are matrixes that reflect influence of $i$-th component of $\mathrm{W}$ matrix on $j$-th component.

The solution of the ANP task is the boundary supermatrix, and its elements are quantitative relative estimates of the impact of one element of the network on another in the scale of relations [10]. To obtain boundary supermatrix, it must be reduced to integer degrees, that is, to consistently multiply on itself. This is possible because supermatrix is square.

In AHPIANP, for the evaluation of the influence of a system element, the matrices of paired comparisons or the intensity scale [9] are used, therefore these methods simultaneously both relate to descriptive and normative measurement theory. Conducting pair comparisons corresponds to a descriptive approach. Normative approach is shown in the use of expert judgments to create a scale of intensity (linguistic standards), which can be used for a separate assessment of options one by one. The latter approach is known as absolute measurement. This is the approach chosen for the convenience and visibility of the decision support process for this task.

Based on structure of the task, it is necessary to calculate the output of the original supermatrix $W_{12}$, $W_{21}, W_{22}, W_{32}$. First, fill these blocks with the use of scale of intensity, then we will calculate the output and marginal supramatrix using the web application of "DSS Nootron" [18].

We developed the general scale of the intensities for blocks analysis $W_{12}, W_{21}, W_{22}$ that is shown in the table 3.

Table 3 - Scale of intensities (1)

\begin{tabular}{|l|r|}
\hline \multicolumn{1}{|c|}{ Intensity } & Priority \\
\hline Very high & 0.480 \\
\hline High & 0.240 \\
\hline Medium & 0.160 \\
\hline Low & 0.120 \\
\hline
\end{tabular}

We developed a common scale of intensity for analysis of $W_{32}$ block (connection "Criteria" -> "Alternatives"), that is shown in the table 4.

Table 4 - Scale of intensities (2)

\begin{tabular}{|l|r|}
\hline \multicolumn{1}{|c|}{ Intensity } & \multicolumn{1}{|c|}{ Priority } \\
\hline Very high & 0.346 \\
\hline High & 0.202 \\
\hline Moderately high & 0.148 \\
\hline Above medium & 0.118 \\
\hline Medium & 0.100 \\
\hline Low & 0.086 \\
\hline
\end{tabular}

These scales (Table 3, 4) were obtained using Zipf - Pareto law with the ratio of the first and last element of the scale - 4 (as in the classical ratio - 0,8/0,2). 


\section{Розділ 3 Інноваційний менеджмент}

Evaluation of the importance of the criteria relative to the goals to the scale of intensities 1 (Table 3), i.e. the connection "Goals" -> "Criteria" or block W12 the output supermatrix is shown in the table 5.

Table 5 - Connection "Goals" -> "Criteria", block W12

\begin{tabular}{|l|l|c|c|c|c|c|}
\hline \multicolumn{2}{|c|}{ Control components } & \multicolumn{5}{c|}{ Comparable components } \\
\cline { 3 - 6 } & \multicolumn{2}{|c|}{ Cr1 } & Cr2 & Cr3 & Cr4 & Cr5 \\
\hline Goal 1 & $\begin{array}{l}\text { choice a form of protection for obtaining exclusive } \\
\text { rights to a computer program }\end{array}$ & Very high & Medium & High & High & Low \\
\hline Goal 2 & $\begin{array}{l}\text { the choice of the form of protection for the further } \\
\text { commercialization of the computer program }\end{array}$ & High & Low & High & High & Low \\
\hline
\end{tabular}

Here, "Control Components" are the components for which comparison is performed.

The result of feedback analysis "Criteria" -> "Goals" is given in Table 6.

Table 6 - Connection "Criteria" -> "Goals", block W21

\begin{tabular}{|c|c|c|c|c|c|c|}
\hline \multirow{3}{*}{\multicolumn{2}{|c|}{ Comparable components }} & \multicolumn{5}{|c|}{ Control criteria } \\
\hline & & MAX & MIN & MIN & MIN & MAX \\
\hline & & $\mathrm{Cr} 1$ & $\mathrm{Cr} 2$ & $\mathrm{Cr} 3$ & $\mathrm{Cr} 4$ & $\mathrm{Cr} 5$ \\
\hline Goal 1 & $\begin{array}{l}\text { choice a form of protection for obtaining } \\
\text { exclusive rights to a computer program }\end{array}$ & Very high & High & High & Low & Medium \\
\hline Goal 2 & $\begin{array}{l}\text { choice of the form of protection for the further } \\
\text { commercialization of the computer program }\end{array}$ & Low & Medium & High & Very high & High \\
\hline
\end{tabular}

The marks "MAX" and "MIN" correspond to the condition of calculating the priorities according to the criterion, respectively: "the more, the better" and "the smaller, the better".

The following table 7 evaluates the impact of the criteria one on another, which corresponds to the block $W_{22}$. Here the criteria in rows were evaluated by the level of influence on the criteria in the columns.

\section{Table 7 - Connection "Criteria" -> "Criteria", block W/2}

\begin{tabular}{|c|l|c|c|c|c|c|}
\hline \multicolumn{2}{|c|}{ Comparable components } & \multicolumn{5}{c|}{ Control criteria } \\
\cline { 3 - 7 } & The size of legal protection & Cr1 & Cr2 & Cr3 & Cr4 & Cr5 \\
\hline Cr1 & - & Medium & High & High & Low \\
\hline Cr2 & Conditions of acquiring rights & Medium & - & High & High & Medium \\
\hline Cr3 & Complexity of expertise & Medium & Medium & - & High & Medium \\
\hline Cr4 & Expenses during the acquisition of copyrights & Medium & Medium & High & - & Medium \\
\hline Cr5 & Duration of property rights protection & Low & Low & Medium & Medium & - \\
\hline
\end{tabular}

Estimation of the alternatives priorities for each criterion on the scale of intensities 2 (Table 4), block $W_{32}$ the output supermatrix is shown in the table 8.

\section{Table 8 - Connection "Criteria"-> "Alternatives", block W32}

\begin{tabular}{|c|l|c|c|c|c|c|}
\hline \multirow{2}{*}{ Comparable components } & \multicolumn{5}{|c|}{ Control criteria } \\
\cline { 3 - 7 } & MAX & MIN & MIN & MIN & MAX \\
\cline { 2 - 7 } & Cr1 & Cr2 & Cr3 & Cr4 & Cr5 \\
\hline A1 & CCR & Low & Low & Low & Low & Very high \\
\hline A2 & SGS & Medium & Medium & Medium & Medium & Above medium \\
\hline A3 & Patent & Moderately high & Moderately high & Moderately high & Moderately high & Medium \\
\hline A4 & CCR + SGS & Above medium & Above medium & Above medium & Above medium & High \\
\hline A5 & Patent + SGS & High & High & High & High & Medium \\
\hline A6 & Patent + CCR & Moderately high & Moderately high & Moderately high & Moderately high & Moderately high \\
\hline A7 & Patent + CCR + SGS & Very high & Very high & Very high & Very high & High \\
\hline
\end{tabular}


І.Є.Драч, ГЛ. Євтушенко. Прийняття управлінських рішень у сфері інтелектуальної власності на основі багатокритеріального аналізу

With the use of DSS Nootron [18], the output (Table 9) and boundary supermatrixes (Table 10) are calculated, as well as the global priorities of the alternatives.

Table 9 - Output supermatrix

\begin{tabular}{|c|c|c|c|c|c|c|c|c|c|c|c|c|c|c|}
\hline Nod & Goal1 & Goal2 & $\mathrm{Cr} 1$ & $\mathrm{Cr} 2$ & $\mathrm{Cr} 3$ & $\mathrm{Cr} 4$ & $\mathrm{Cr} 5$ & $\mathrm{~A} 1$ & $\mathrm{~A} 2$ & $\mathrm{~A} 3$ & $\mathrm{~A} 4$ & $\mathrm{~A} 5$ & $\mathrm{~A} 6$ & A7 \\
\hline Goal1 & $\overline{0}$ & $\overline{0}$ & 0,800 & 0,400 & 0,500 & 0,800 & 0,400 & 0 & 0 & 0 & 0 & 0 & 0 & 0 \\
\hline Goal2 & 0 & 0 & 0,200 & 0,600 & 0,500 & 0,200 & 0,600 & 0 & 0 & 0 & 0 & 0 & 0 & 0 \\
\hline $\mathrm{Cr} 1$ & 0,387 & 0,250 & 0 & 0,266 & 0,273 & 0,273 & 0,200 & 0 & 0 & 0 & 0 & 0 & 0 & 0 \\
\hline $\mathrm{Cr} 2$ & 0,129 & 0,125 & 0,266 & 0 & 0,273 & 0,273 & 0,266 & 0 & 0 & 0 & 0 & 0 & 0 & 0 \\
\hline $\mathrm{Cr} 3$ & 0,194 & 0,250 & 0,267 & 0,267 & 0 & 0,273 & 0,267 & 0 & 0 & 0 & 0 & 0 & 0 & 0 \\
\hline $\mathrm{Cr} 4$ & 0,194 & 0,250 & 0,267 & 0,267 & 0,273 & 0 & 0,267 & 0 & 0 & 0 & 0 & 0 & 0 & 0 \\
\hline $\mathrm{Cr} 5$ & 0,096 & 0,125 & 0,200 & 0,200 & 0,181 & 0,181 & 0 & 0 & 0 & 0 & 0 & 0 & 0 & 0 \\
\hline A1 & $\overline{0}$ & $\overline{0}$ & 0,075 & 0,227 & 0,227 & 0,227 & 0,285 & 1 & 0 & 0 & 0 & 0 & 0 & 0 \\
\hline $\mathrm{A} 2$ & 0 & 0 & 0,087 & 0,194 & 0,194 & 0,194 & 0,097 & 0 & 1 & 0 & 0 & $0^{-}$ & 0 & 0 \\
\hline $\mathrm{A} 3$ & 0 & 0 & 0,129 & 0,131 & 0,131 & 0,131 & 0,082 & 0 & 0 & 1 & 0 & 0 & 0 & 0 \\
\hline A4 & 0 & 0 & 0,103 & 0,165 & 0,165 & 0,165 & 0,166 & 0 & 0 & 0 & 1 & 0 & 0 & 0 \\
\hline $\mathrm{A} 5$ & 0 & 0 & 0,176 & 0,096 & 0,096 & 0,096 & 0,082 & 0 & 0 & 0 & 0 & 1 & 0 & 0 \\
\hline$A 6$ & 0 & 0 & 0,129 & 0,131 & 0,131 & 0,131 & 0,122 & 0 & 0 & 0 & 0 & 0 & 1 & 0 \\
\hline$A 7$ & 0 & 0 & 0,301 & 0,056 & 0,056 & 0,056 & 0,166 & 0 & 0 & 0 & 0 & 0 & 0 & 1 \\
\hline
\end{tabular}

Table 10 - Boundary supermatrix

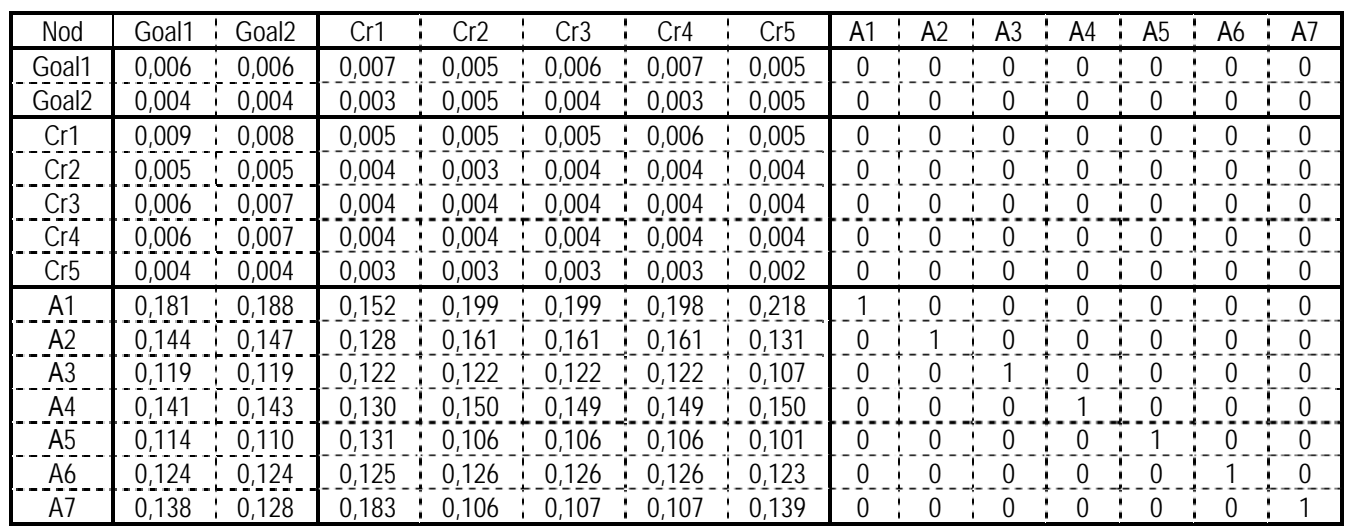

The obtained values in block $W_{31}$ is a solution of the problem by analytic network process. The generalized result for this block, and the priorities are calculated separately for each goal by the analytic hierarchy process, are given in table. 11.

\section{Table 11 - Priorities for alternatives by AHP and ANP}

\begin{tabular}{|l|l|r|r|r|}
\hline \multicolumn{2}{|c|}{ Alternatives } & \multicolumn{2}{c|}{ AHP } & \multirow{2}{*}{ ANP } \\
\cline { 3 - 5 } & & Goal 1 & \multicolumn{1}{c|}{ Goal 2 } & \\
\hline A1 & CCR & 0,174 & 0,196 & 0,192 \\
\hline A2 & SGS & 0,143 & 0,155 & 0,152 \\
\hline A3 & Patent & 0,126 & 0,124 & 0,124 \\
\hline A4 & CCR + SGS & 0,141 & 0,150 & 0,148 \\
\hline A5 & Patent + SGS & 0,126 & 0,114 & 0,117 \\
\hline A6 & Patent + CCR & 0,129 & 0,129 & 0,129 \\
\hline A7 & Patent + CCR + SGS & 0,161 & 0,131 & 0,138 \\
\hline
\end{tabular}


The relative priorities of the alternatives are illustrated in the diagram in Fig. 3. Here, the global priority of a better alternative is $100 \%$.

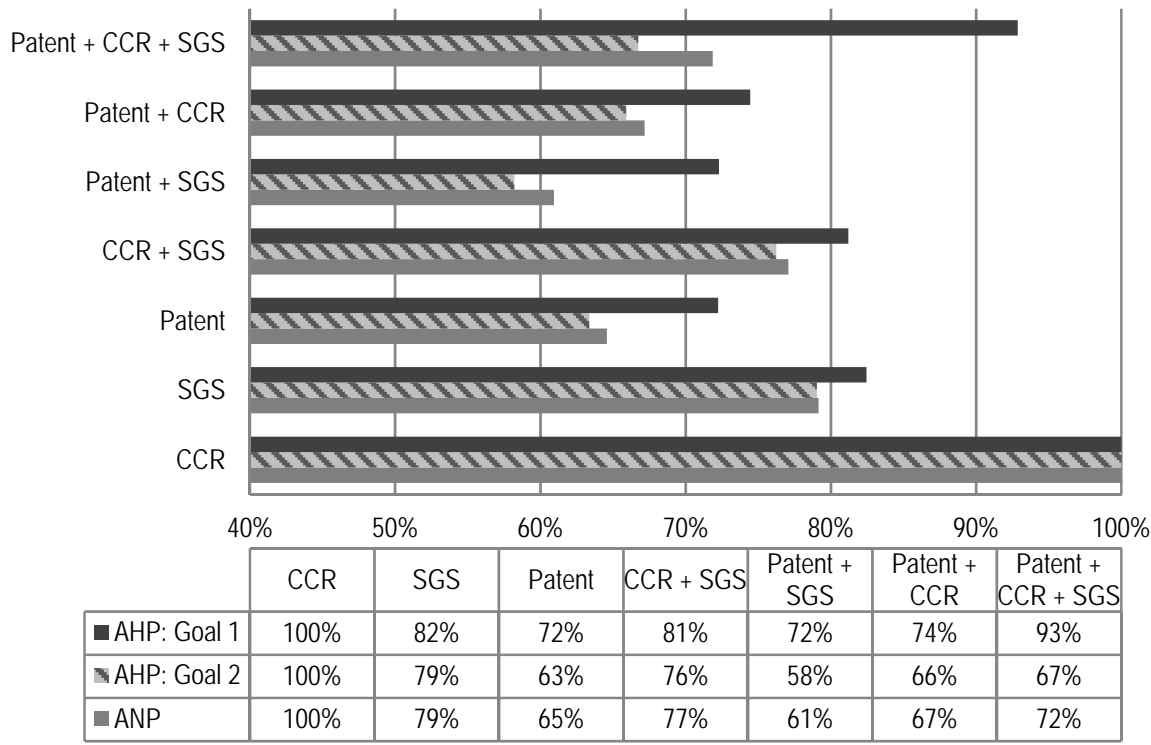

Figure 3 - Diagram of priorities alternatives by AHP and ANP

As a result of the analysis for both goals by the AHPIANP methods the best alternative, a variant of the legal protection of a computer program was a registration copyright certificate to a work. Although this option has a low rating for an important criterion, size of legal protection (Cr1), - it received high marks for others, which put him in first place.

It is also necessary to pay attention to the complex alternative - Patent + CCR + SGS (Patent for invention + Certificate of work registration copyright + Certificate of a sign for goods and services). It is the second goal for obtaining exclusive copyrights and is better on criterion $\mathrm{Cr} 1$, but because of low ratings on the criteria related to the complexity of obtaining this version of the protection document, ranked fourth by the ANP.

The obtained result does not contradict with the reality, because at the legislative level, copyright is the main form of legal protection of a computer program. Note that the solved problem is a model, and the result may vary depending on the evaluation of the criteria and priorities of alternatives.

Conclusions and prospects for further developments. Based on the analysis of methods of legal protection of computer programs, we identified the goals, criteria and alternatives that are important at the stage of acquiring rights to a computer program. A graph has been constructed for these elements and based on this, appropriate, multi-criteria methods have been selected - AHP / ANP. Based on the developed scale of intensity the estimation of the priorities of the components of the set system task was conducted. We made the priorities diagram for protection methods, obtained by analytic network process and analytic hierarchy process; the analysis of the received results was carried out.

The proposed methodology allowed to systematize the decision support process and can be used in the management of the object life cycle of intellectual property rights. The use of the DSS NooTron during multi-criteria analysis ensured the efficiency of the process.

The continuation of research in this area is the development of a decision support model of managerial decisions at various stages of the object life cycle of intellectual property rights. 
1. What is Intellectual Property? [Electronic resource]. - Mode of access: http://www.wipo.int/about-ip/en/

2. Ц Цибульов П.М. Управління інтелектуальною власністю / П.М. Цибульов, В.П. Чеботарьов, В.Г. Зінов, Ю. Суіні; За ред. П.М. Цибульова: монографія. - Київ : «К.І.С.», 2005. - 448 с.

3. Паладій М.В. Проблеми формування управлінських рішень у сфері інтелектуальної власності України в умовах інтеграції в світові співтовариства [Електронний ресурс] / М.В. Паладій // Державне управління: удосконалення та розвиток. - 2012. - № 6. - Режим доступу: http://nbuv.gov.ua/UJRN/Duur_2012_6_3

4. Водорєзова С.Р. Особливості правової охорони комп'ютерної програми як об'єкта інфформаційних відносин / С.Р. Водорєзова // Право та інновації. - 2014. - № 3. - С. 69-76.

5. Жуванов Д. Яку форму правової охорони обрати для комп'ютерної програми? [Електронний ресурс] / Д. Жуванов, Є. Стогній // Патентна агенція Д. Романенка. - Режим доступу: http://www.romanenko.biz/ua/library/article_program.html.

6. Філик Н.В. Компютерна програма як об'єкт авторського права: проблеми правової охорони / Н.В. Філик, Г.В. Омельченко // Юридичний вісник. - 2016. - №2 (39). - С.130-137.

7. Петренко С.А. Правова охорона комп'ютерної програми як об'єкта інтелектуальної власності: шляхи розвитку: автореф. дис. ... канд. юрид. наук: 12.00 .03 / С.А. Петренко. - Київ: Науково-дослідний інститут приватного права підприємництва Академії правових наук України, 2010. - 16 с.

8. Єфрремова К.В. Правова природа комп'ютерної програми як об'єкту інноваційних відносин / К.В. Єфремова // Актуал. питання інновац. розвитку. - 2012. - № 2. - С. 24-29.

9. Story A. Intellectual Property and Computer Software: A Battle of Competing Use and Access Visions for Countries of the South [Electronic resource] / A. Story // United Nations Conference on Trade and Sustainable Development. - Geneva: ICTSD and UNCTAD, 2004. - №10. - 46 p. - Mode of access: http://iprsonline.org/unctadictsd/docs/CS_Story.pdf.

10. Ballardini R.M. Intellectual property protection for computer programs: Developments, challenges, and pressures for change [Text] / R.M. Ballardini - Helsinki: Edita Prima Ltd, 2012. - 233 p.

11. Shaikh S.A. Intricacies of Software Protection: A Techno-Legal Review / S.A. Shaikh, B.R Londhe // Journal of Intellectual Property Rights. - India: NISCAIR-CSIR, 2016. - Vol 21(3). - P. 157 - 165.

12. Правовая охрана компьютерных программ и баз данных / Е.А. Боровская, С.Л. Ермакович, В.И. Кудашов, С.С. Лосев, А.А. Успенский. - Минск: Государственный комитет по науке и технологиям Республики Беларусь, 2010. - 246 с

13. Саати Т.Л. Принятие решений при зависимостях и обратных связях: Аналитические сети / Т.Л.Саати. - М.: Изд-во ЛКИ, 2008. -360 c

14. Saaty T.L. On the Measurement of Intangibles: A principal eigenvector approach to relative measurement derived from paired comparisons / T.L. Saaty // Notices of the American Mathematical Society. - 2013. - Vol. 60(2) - P. 192-208.

15. Закон України «Про авторські і суміжні права» від 23.12.1993 № 3792-ХІІ [Електронний ресурс] // Офіційний вебпортал Верховної Ради України. - Режим доступу: http://zakon3.rada.gov.ua/laws/show/3792-12.

16. Закон України «Про охорону прав на винаходи і корисні моделі» від 15.12.1993 № 3687-ХІІ [Електронний ресурс] /I Офіційний веб-портал Верховної Ради України. - Режим доступу: http://zakon3.rada.gov.ua/laws/show/3687-12.

17. Закон України «Про охорону прав на знаки для товарів і послуг» від 15.12.1993 № 3689-ХІІ [Електронний ресурс] // Офіційний веб-портал Верховної Ради України. - Режим доступу: http://zakon3.rada.gov.ua/laws/show/3689-12.

18. Система поддержки принятия решений NooTron [Электронный ресурс]. - Режим доступа : http://nootron.net.ua.

1. WIPO (n.d.). What is Intellectual Property? wipo.int. Retrieved from http://www.wipo.int/about-ip/en/.

2. Tsybulov, P.M., Chebotarov, V.P., Zinov, V.H., \& Suini, Yu. (2005). Upravlinnia intelektualnoiu vlasnistiu [Management of intellectual property]. Kyiv : K.I.S. [in Ukrainian].

3. Paladii, M.V. (2012). Problemy formuvannia upravlinskykh rishen u sferi intelektualnoi vlasnosti Ukrainy v umovakh intehratsii v svitovi spivtovarystva [Problems of management decisions on intellectual property in the integration of Ukraine into the world community]. Derzhavne upravlinnia: udoskonalennia ta rozvytok - Public administration, improvement and development, 6. Retrieved from http://nbuv.gov.ua/UJRN/Duur_2012 63 [in Ukrainian].

4. Vodoriezova S.R. (2014). Osoblyvosti pravovoi okhorony komp'iuternoi prohramy yak ob'iekta informatsiinykh vidnosyn [Features of the legal protection of computer programs as object information relations]. Pravo ta innovatsii - Right and innovation, $3,69-76$ [in Ukrainian].

5. Zhuvanov, D., \& Stohnii, le. Yaku formu pravovoi okhorony obraty dlia komp'iuternoi prohramy? [What form of legal protection of computer programs to choose?] (n.d.). Patentna ahentsiia D. Romanenka - Patent agency Romanenko D. romanenko.biz. Retrieved from http://www.romanenko.biz/ua/library/article_program.html [in Ukrainian].

6. Filyk, N.V., \& Omelchenko, H.V. (2016). Kompiuterna prohrama yak ob'iekt avtorskoho prava: problemy pravovoi okhorony [Computer program as an object of copyright: problems of legal protection]. Yurydychnyi visnyk - Legal Bulletin, 2 (39), 130-137 [in Ukrainian].

7. Petrenko, S.A. (2010). Pravova okhorona kompiuternoi prohramy yak obiekta intelektualnoi vlasnosti: shliakhy rozvytku. [Legal protection of a computer program as an object of intellectual property: ways of development]. Extended abstract of candidate's thesis. Kyiv [in Ukrainian].

8. Yefremova, K.V. (2012). Pravova pryroda kompiuternoi prohramy yak obiektu innovatsiinykh vidnosyn [The legal nature of the computer program as an object of innovative relations]. Aktualni pytannia innovatsiinoho rozvytku - Topical issues of innovation 
development, 2, 24-29 [in Ukrainian].

9. Story, A. (2004). Intellectual Property and Computer Software: A Battle of Competing Use and Access Visions for Countries of the South. United Nations Conference on Trade and Sustainable Development. Geneva: ICTSD and UNCTAD. Retrieved from http://iprsonline.org/unctadictsd/docs/CS Story.pdf.

10. Ballardini, R.M. (2012). Intellectual property protection for computer programs: Developments, challenges, and pressures for change. Helsinki : Edita Prima Ltd.

11. Shaikh, S.A., \& Londhe, B.R. (2016). Intricacies of Software Protection: A Techno-Legal Review. - Journal of Intellectual Property Rights, 21(3), 157 - 165 [in English].

12. Borovskaya, E.A., Yermakovich, S.L., Kudashov, V.I., Losev, S.S., \& Uspenskiy, A.A. (2010) Pravovaya okhrana komp'yuternykh programm i baz dannykh [Legal protection of computer programs and databases]. Minsk: Gosudarstvennyy komitet po nauke i tekhnologiyam Respubliki Belarus [in Russian].

13. Saati, T.L. (2008). Prinyatie resheniy pri zavisimostyah i obratnyih svyazyah: Analiticheskie seti [Decision-making at the dependencies and feedbacks: Analytical Network]. Moskow: LKI [in Russian].

14. Saaty, T.L. (2013). On the Measurement of Intangibles. A Principal Eigenvector Approach to Relative Measurement Derived from Paired. Notices of the American Mathematical Society, 60(2), 192-208.

15. Zakon Ukrainy «Pro avtorski i sumizhni prava» vid 23.12.1993 № 3792-XII [Law of Ukraine «On copyright and related rights» from 15.12.93, № 3687-XII amended] (1993). Ofitsiinyi veb-portal Verkhovnoi Rady Ukrainy - Official Web Portal Verkhovna Rada of Ukraine. Retrieved from http://zakon3.rada.gov.ua/laws/show/3792-12 [in Ukrainian].

16. Zakon Ukrainy «Pro okhoronu prav na vynakhody i korysni modeli» vid 15.12.1993 № 3687-XII [Law of Ukraine «On the protection of rights to inventions and utility models» from 15.12.1993, №3687-XII] (1993). Ofitsiinyi veb-portal Verkhovnoi Rady Ukrainy - Official Web Portal of Verkhovna Rada of Ukraine. Retrieved from http://zakon3.rada.gov.ua/laws/show/3687-12 [in Ukrainian].

17. Zakon Ukrainy «Pro okhoronu prav na znaky dlia tovariv i posluh» vid 15.12.1993 № 3689-XII [The Law of Ukraine «On protection of rights to trademarks for goods and services» from 15.12.1993, № 3689-XII] (1993). Ofitsiinyi veb-portal Verkhovnoi Rady Ukrainy - Official Web Portal of Verkhovna of Rada of Ukraine. Retrieved from http://zakon3.rada.gov.ua/laws/show/3689-12 [in Ukrainian].

18. Sistema podderzhki prinyatiya resheniy NooTron [Decision support system NooTron] (n.d.). nootron.net.ua. Retrieved from http://nootron.net.ua [in Russian].

I.€. Драч, канд. техн. наук, доцент кафедри інтелектуальної власності та управління проектами, Національна металургійна академія України (м. Дніпро, Україна);

ГЛ. Єөтушенко, канд. техн. наук, доцент кафедри інформаційних технологій і систем, Національна металургійна академія України (м. Дніпро, Україна)

Прийняття управлінських рішень у сфері інтелектуальної власності на основі багатокритеріального аналізу

Розглянуто процес підтримки прийняття управлінських рішень на етапі набуття прав на комп'ютерну програму на основі методів багатокритеріального аналізу. Досліджено способи правової охорони комп'ютерної програми: як літературного твору, винаходу і знака для товарів і послуг. Охарактеризовано форми правової охорони комп'ютерної програми за критеріями: обсяг правової охорони; умови набуття прав; складність експертизи; витрати під час набуття прав інтелектуальної власності; тривалість охорони майнових прав. На базі розробленої шкали інтенсивност проведено оцінку пріоритетів способів охорони за кожним критерієм. Побудовано діаграму пріоритетів способів охорони методом аналізу мереж та методом аналізу ієрархії.

Ключові слова: інтелектуальна власність, комп'ютерна програма, правова охорона, комерціалізація, метод аналізу мереж, метод аналізу ієрархій.

И.Е. Драч, канд. техн. наук, доцент кафедры интеллектуальной собственности и управления проектами, Национальная металлургическая академия Украины (г. Днепр, Украина);

ГЛ. Еөтушенко, канд. техн. наук, доцент кафедры информационных технологий и систем, Национальная металлургическая академия Украины (г. Днепр, Украина)

Принятие управленческих решений в сфере интеллектуальной собственности на основе многокритериального анализа

Рассмотрен процесс поддержки принятия управленческих решений на этапе приобретения прав на компьютерную программу на основе методов многокритериального анализа. Исследованы способы правовой охраны компьютерной программы: как литературного произведения, изобретения и знака для товаров и услуг. Охарактеризованы формы правовой охраны компьютерной программы по критериям: объем правовой охраны; условия приобретения прав; сложность экспертизы; расходы при приобретении прав интеллектуальной собственности; продолжительность охраны имущественных прав. На базе разработанной шкалы интенсивности проведена оценка приоритетов способов охраны по каждому критерию. Построена диаграмма приоритетов способов охраны методом анализа сетей и методом анализа иерархий.

Ключевые слова: интеллектуальная собственность, компьютерная программа, правовая охрана, коммерциализация, метод анализа сетей, метод анализа иерархий.

Отримано 29.03.2017p. 